
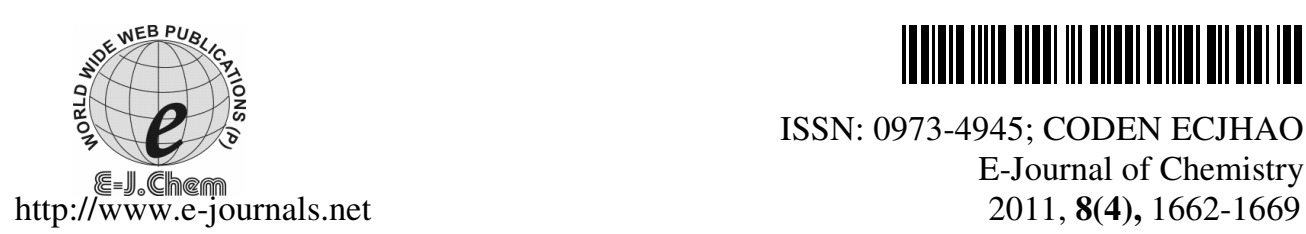

ISSN: 0973-4945; CODEN ECJHAO

E-Journal of Chemistry

2011, 8(4), 1662-1669

\title{
Synthesis, Characterization and Antibacterial Studies of Some Transition Metal Complexes of a Schiff Base Derived from 2-(Aminomethyl)- benzimidazole and Thiophene-2-carbaxaldehyde
}

\author{
PRAGATHI JOGI $^{\S}, \mathrm{K} M O U N I K A^{\S}$, M PADMAJA $^{\S}$, \\ LAKSHMI M and C GYANAKUMARI ${ }^{\S *}$ \\ ${ }^{\S}$ Department of Chemistry \\ Osmania University, Hyderabad-500 007, India
}

National Geophysical Research Institute (NGRI), Hyderabad, India

munni_pragathi@yahoo.co.uk

Received 25 January 2011; Accepted 13 April 2011

\begin{abstract}
Complexes of $\mathrm{Cu}(\mathrm{II}), \mathrm{VO}(\mathrm{IV}), \mathrm{Mn}(\mathrm{II}), \mathrm{Co}(\mathrm{II}), \mathrm{Ni}(\mathrm{II})$ and $\mathrm{Zn}$ (II) with a Schiff base derived from 2-(aminomethyl)benzimidazole and thiophene-2carbaxaldehyde (1-(1H-benzimidazol-2-yl)- $N-[(E)$ thiophenylmethylidene $]$ methanamine-BNTM) were successfully synthesized. The complexes have been characterized using chemical analysis, spectroscopic methods (IR, UV-Visible, ${ }^{1} \mathrm{H}$ - NMR, ${ }^{13} \mathrm{C}-\mathrm{NMR}$ and ESR), Thermal studies, conductometric and magnetic data. According to these data, we proposed an octahedral geometry to all the metal complexes. Antibacterial activity of the ligand and its metal complexes were studied against two gram-negative bacteria; Escherichia coli, Pseudomonas aeruginosa and two gram-positive bacteria; Bacillus subtilis, Staphylococcus aureus. It has been found that all the complexes are antimicrobially active and show higher activity than ligand.
\end{abstract}

Keywords: Schiff base, 2-(Aminomethyl)benzimidazole, Thiophene-2-carbaxaldehyde, Synthesis

\section{Introduction}

A large number of Schiff bases and their complexes have significant interest and attention because of their biological activity, including antitumor, anti bacterial, fungicidal and anti carcinogenic properties ${ }^{1-5}$. Transition metal complexes of Schiff bases have applications in clinical and analytical and industrial in addition to their important roles in a catalysis and organic synthesis ${ }^{6}$. Benzimidazoles are very useful intermediates/subunits for the development of molecules of pharmaceutical or biological interest. Substituted benzimidazole derivatives have found applications in diverse therapeutic areas, including anti ulcers, anti-hypertensive, anti-virals, anti-fungals, anti-cancers and anti histaminic ${ }^{7,8}$. Heterocyclic ring containing sulphur, nitrogen and oxygen impart biological activity to these 
Schiff bases and their metal complexes. In view of the interesting ligating behavior of such systems, we considered it worthwhile to prepare $\mathrm{Cu}(\mathrm{II}), \mathrm{Co}(\mathrm{II}), \mathrm{Ni}(\mathrm{II}), \mathrm{VO}(\mathrm{IV}), \mathrm{Mn}$ (II) and $\mathrm{Zn}$ (II) complexes of tridentate ligand derived from 2-(aminomethyl)benzimidazole and thiophene-2-carbaxaldehyde. These complexes have been characterized by various physiochemical methods.

\section{Experimental}

All the chemicals used were of analytical grade. 2-(Aminomethyl)benzimidazole and thiophene-2-carbaxaldehyde was of sigma aldrich chemicals. Vanadylsulphate, copper chloride, nickel chloride, zinc acetate, manganese chloride and cobalt chloride were of SD's fine chemicals.

\section{Instrumentation}

The percentage compositions of $\mathrm{C}, \mathrm{H}$ and $\mathrm{N}$ of complexes were determined by using micro analytical methods on Perkin Elmer 240C (USA) elemental analyzer. Infrared spectra of the ligand and its complexes were carried out by using $\mathrm{KBr}$ pellets in the range $4000-400 \mathrm{~cm}^{-1}$ on Perkin Elmer Infra red model 337. The electronic absorption was carried out by Shimadzu UV-1601 using DMSO as solvent. TGA studies were carried on Mettler Toledo Star system in the temperature range of $0-1000{ }^{\circ} \mathrm{C}$. The Mass spectra were recorded by ESI technique on VG AUTOSPEC mass spectrometer instrument. The ${ }^{1} \mathrm{H}$ and ${ }^{13} \mathrm{C}$ NMR spectra were recorded on Varian Gemini Unity Spectrometer by employing TMS as internal standard. Melting points of the ligand and decomposition temperature of complexes were determined on Polmon instrument (model No.MP-96). The Molar conductance measurements were carried out in DMSO $\left(10^{-3} \mathrm{M}\right)$ using Digisun electronic digital conductivity meter of model; DI-909 having a dip-type cell calibrated with $\mathrm{KCl}$. The magnetic susceptibilities of complexes were determined on Gouy balance model 7550 at $23{ }^{\circ} \mathrm{C}$. The diamagnetic corrections was carriedout using a Shimadzu UV-1601 using DMSO as solvent. TGA studies were carried on Mettler Toledo Star system in the temperature range of $0-1000{ }^{\circ} \mathrm{C}$. The mass spectra were recorded by ESI technique on VG AUTOSPEC mass spectrometer were made by Pascal's constant and $\mathrm{Hg}\left[\mathrm{Co}(\mathrm{SCN})_{4}\right]$ was used as a calibrant. ESR spectra were recorded in DMSO solution on a JOEL.TE-3X.X-Band spectrometer equipped with a $100 \mathrm{KHZ}$ field modulation unit, central university, Hyderabad.

\section{Synthesis of Schiff base}

2-(Aminomethyl)benzimidazole $(1.10 \mathrm{~g}, 5 \mathrm{mmol})$ was dissolved in $15 \mathrm{~mL}$ water and neutralized by adding aqueous $\mathrm{Na}_{2} \mathrm{CO}_{3}$ solution. A stirred solution of thiophene-2carbaxaldehyde $(0.560 \mathrm{~g}, 5 \mathrm{mmol})$ in $8 \mathrm{~mL}$ of methanol was added drop wise to the above solution with stirring for $1 \mathrm{~h}$. During this period, yellow solid slowly separated out. The solid was filtered off, washed thoroughly with water followed by petroleum ether and dried in vacuum at room temperature. Structure of the Schiff base is shown in the Figure 1.

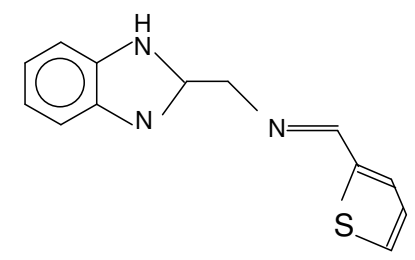

Figure 1. Structure of Schiff base 


\section{Synthesis of metal complexes}

Methanolic solution of ligand $(0.005 \mathrm{~mol})$ and methanolic solution of corresponding metal salts $(0.005 \mathrm{~mol})\left(\mathrm{MX}_{2}\right.$, where $\mathrm{M}=\mathrm{Cu}(\mathrm{II}), \mathrm{Ni}(\mathrm{II}), \mathrm{Co}(\mathrm{II}), \mathrm{Zn}(\mathrm{II}), \mathrm{Mn}(\mathrm{II})$ and $\mathrm{VO}(\mathrm{IV})$; $\mathrm{X}=\mathrm{Cl} /$ Acetate $/ \mathrm{SO}_{4}$ ) were mixed together with constant stirring. The mixture was refluxed for $4 \mathrm{~h}$ at $80{ }^{\circ} \mathrm{C}$. On cooling colored solid metal complexes were precipitated out. The products were filtered, washed with petroleum ether and dried under vacuum over $\mathrm{CaCl}_{2}$.

\section{Results and Discussion}

The complexes were found to be stable in air and non-hygroscopic. The complexes are soluble in DMSO. The physical properties and analytical data of the complexes are given in Table 1.

Table 1. Physical properties and analytical data of Schiff base and its metal complexes

\begin{tabular}{|c|c|c|c|c|c|c|c|c|}
\hline & & & & & Founc & d (calcula & ted) $\%$ & \\
\hline Compound & Mass & ${ }^{\circ} \mathrm{C}$ & ¿o & $\mathrm{C}$ & $\mathrm{H}$ & $\mathrm{N}$ & $S$ & M \\
\hline BNTM & 244 & 135 & - & $\begin{array}{c}64.3 \\
(64.7)\end{array}$ & $\begin{array}{c}4.53 \\
(4.59)\end{array}$ & $\begin{array}{c}17.39 \\
(17.41)\end{array}$ & $\begin{array}{c}13.27 \\
(13.29)\end{array}$ & - \\
\hline$\left[\mathrm{Cu}(\mathrm{BNTM}) \mathrm{Cl}_{2} \mathrm{H}_{2} \mathrm{O}\right]^{+2}$ & 392 & 175 & 28 & $\begin{array}{c}39.4 \\
(39.7)\end{array}$ & $\begin{array}{c}3.31 \\
(3.31)\end{array}$ & $\begin{array}{c}10.54 \\
(10.7)\end{array}$ & $\begin{array}{c}8.03 \\
(8.16)\end{array}$ & $\begin{array}{c}16.22 \\
(16.19)\end{array}$ \\
\hline$\left[\mathrm{Co}(\mathrm{BNTM}) \mathrm{Cl}_{3}\right] \mathrm{Cl} \cdot \mathrm{H}_{2} \mathrm{O}$ & 406.5 & 220 & 67 & $\begin{array}{c}38.5 \\
(38.3)\end{array}$ & $\begin{array}{c}2.6 \\
(2.7)\end{array}$ & $\begin{array}{c}10.33 \\
(10.31)\end{array}$ & $\begin{array}{l}7.85 \\
(7.8)\end{array}$ & $\begin{array}{c}14.31 \\
(14.25)\end{array}$ \\
\hline$\left[\mathrm{Ni}(\mathrm{BNTM}) \mathrm{Cl}_{3}\right] \mathrm{Cl}$ & 406 & $>300$ & 106 & $\begin{array}{l}38.26 \\
(38.2)\end{array}$ & $\begin{array}{c}2.64 \\
(2.69)\end{array}$ & $\begin{array}{c}10.32 \\
(10.29)\end{array}$ & $\begin{array}{c}7.83 \\
(7.84)\end{array}$ & $\begin{array}{c}14.47 \\
(14.46)\end{array}$ \\
\hline$\left[\mathrm{Zn}(\mathrm{BNTM}) \mathrm{Cl}_{2} \mathrm{H}_{2} \mathrm{O}\right]^{+2}$ & 397 & 239 & 8 & $\begin{array}{l}39.25 \\
(39.2)\end{array}$ & $\begin{array}{c}3.28 \\
(3.27)\end{array}$ & $\begin{array}{c}10.54 \\
(10.57)\end{array}$ & $\begin{array}{c}8.05 \\
(8.06)\end{array}$ & $\begin{array}{c}16.39 \\
(16.37)\end{array}$ \\
\hline$[\mathrm{Mn}(\mathrm{BNTM}) \mathrm{Cl} 3] \mathrm{Cl}$ & 401 & 285 & 64 & $\begin{array}{c}38.8 \\
(38.9)\end{array}$ & $\begin{array}{c}2.79 \\
(2.74)\end{array}$ & $\begin{array}{c}10.49 \\
(10.47)\end{array}$ & $\begin{array}{c}7.99 \\
(7.98)\end{array}$ & $\begin{array}{c}13.7 \\
(13.74)\end{array}$ \\
\hline$[\mathrm{VO}(\mathrm{BNTM}) \mathrm{SO} 4]^{+2} \cdot \mathrm{H}_{2} \mathrm{O}$ & 391 & 258 & 13 & $\begin{array}{c}39.87 \\
(39.89)\end{array}$ & $\begin{array}{c}2.84 \\
(2.81)\end{array}$ & $\begin{array}{c}10.73 \\
(10.74)\end{array}$ & $\begin{array}{l}16.25 \\
(16.3)\end{array}$ & $\begin{array}{c}13.06 \\
(13.04)\end{array}$ \\
\hline
\end{tabular}

\section{IR spectral studies}

The most important infrared spectral bands that provide conclusive structural evidence for the coordination of the ligands to the central metal ions are given in the Table 2 . The ligand shows a strong band at $1623 \mathrm{~cm}^{-1}$ characteristic of $v(\mathrm{C}=\mathrm{N})$ stretching vibration ${ }^{9}$, but in complexes, the azomethine frequency shows a marked downfield or up field shift indicating coordination through $\mathrm{N}$ atom ${ }^{10}$. Generally the $1 \mathrm{R}$ spectra of the free ligands show a broad band around $3416 \mathrm{~cm}^{-1}$ which can be attributed to NH stretching vibration of benzimidazole moiety. The position of this band remains at nearly the same frequency in the spectra of the metal complexes suggesting the non-coordination of this group ${ }^{11}$. Appearance of a broad band around $3300 \mathrm{~cm}^{-1}$ region was observed in the spectra of metal complexes indicating the presence of coordinated water molecules. Water molecules are coordinated, confirmed by the occurrence of additional band at $815-865 \mathrm{~cm}^{-1}$ arising due to $\mathrm{OH}$ rocking vibrations ${ }^{12}$. Other band of M-N appears at $460-470 \mathrm{~cm}^{-1}$. In addition, vanadyl complex shows a band at 
$978 \mathrm{~cm}^{-1}$ attributed to $\mathrm{V}=\mathrm{O}$ frequency ${ }^{13-16}$. A sharp band at $720 \mathrm{~cm}^{-1}$ due to $v \mathrm{C}-\mathrm{S}-\mathrm{C}$ group in the Schiff base shifted to higher frequency region in the complexes, suggesting the bonding of sulphur of thiophene moiety in the ligand with the metal ion.

Table 2. Characteristic IR bands $\left(\mathrm{cm}^{-1}\right)$ of the compounds studied

\begin{tabular}{crcccc}
\hline Compound & $v \mathrm{CH}=\mathrm{N}$ & $v \mathrm{M}-\mathrm{N}$ & $v \mathrm{M}-\mathrm{OH}$ & $v \mathrm{C}-\mathrm{S}-\mathrm{C}$ & $v \mathrm{~V}=\mathrm{O}$ \\
\hline BNTM & 1617 & - & - & 720 & - \\
Cu-BNTM & 1619 & 431 & 3338,860 & 740 & - \\
Co-BNTM & 1621 & 466 & 3066,855 & 745 & - \\
Ni-BNTM & 1625 & 467 & - & 745 & - \\
Mn-BNTM & 1627 & 434 & - & 747 & - \\
VO-BNTM & 1626 & 463 & 3309,845 & 750 & 978 \\
Zn-BNTM & 1575 & 435 & 3275,855 & 747 & - \\
\hline
\end{tabular}

\section{Electronic spectra and magnetic moment}

The magnetic susceptibility and electronic spectral data of the metal complexes are given in Table 3 . The magnetic susceptibility data showed that all the metal complexes, except zinc complex, are paramagnetic. The values show that the manganese and cobalt complexes are high spin and the zinc complex is diamagnetic. The values are consistent with octahedral geometry, which is further supported by electronic spectral data. The $\mathrm{Cu}$ (II) complex showed one broad band at $12870 \mathrm{~cm}^{-1}$ assignable to the ${ }^{2} \mathrm{Eg} \rightarrow{ }^{2} \mathrm{~T}_{2} \mathrm{~g}$ transition that is characteristic of an octahedral environment ${ }^{17}$. The electronic spectrum of $\mathrm{Co}(\mathrm{II})$ complex showed bands at $15015,20040,26881 \mathrm{~cm}^{-1}$, which are assignable to ${ }^{4} \mathrm{~T}_{1} \mathrm{~g}(\mathrm{~F}) \rightarrow{ }^{4} \mathrm{~T}_{2} \mathrm{~g}(\mathrm{~F})$, ${ }^{4} \mathrm{~T}_{1} \mathrm{~g}(\mathrm{~F}) \rightarrow{ }^{4} \mathrm{~A}_{2} \mathrm{~g}(\mathrm{~F})$ and ${ }^{4} \mathrm{~T}_{1} \mathrm{~g}(\mathrm{P}) \rightarrow{ }^{4} \mathrm{~T}_{1} \mathrm{~g}(\mathrm{~F})$ transitions respectively, that are characteristic of octahedral configuration ${ }^{17}$. The $\mathrm{Ni}(\mathrm{II})$ complex exhibited 3 transitions at 21834,24875 , $30864 \mathrm{~cm}^{-1}$, which are assignable to ${ }^{3} \mathrm{~A}_{2} \mathrm{~g} \rightarrow{ }^{3} \mathrm{~T}_{2} \mathrm{~g}(\mathrm{~F}),{ }^{3} \mathrm{~A}_{2} \mathrm{~g} \rightarrow \mathrm{T}_{1} \mathrm{~g}(\mathrm{~F})$ and ${ }^{3} \mathrm{~A}_{2} \mathrm{~g} \rightarrow{ }^{3} \mathrm{~T}_{1} \mathrm{~g}(\mathrm{P})$ transitions. Electronic spectra of $\mathrm{Mn}(\mathrm{II})$ complex display absorption bands at 21321, 24154, $27173,29411 \mathrm{~cm}^{-1}$, characteristic of octahedral geometry corresponding to ${ }^{6} \mathrm{~A}_{1} \mathrm{~g} \rightarrow{ }^{4} \mathrm{~T}_{1} \mathrm{~g}\left({ }^{4} \mathrm{G}\right)$, ${ }^{6} \mathrm{~A}_{1} \mathrm{~g} \rightarrow{ }^{4} \mathrm{E}_{2} \mathrm{~g}\left({ }^{4} \mathrm{D}\right),{ }^{6} \mathrm{~A}_{1} \mathrm{~g} \rightarrow{ }^{4} \mathrm{~T}_{1} \mathrm{~g}\left({ }^{4} \mathrm{P}\right)$ and ${ }^{6} \mathrm{~A}_{1} \mathrm{~g} \rightarrow{ }^{4} \mathrm{Eg}\left({ }^{4} \mathrm{G}\right)$ transitions respectively.

Table 3. Electronic spectral data and magnetic moment data

\begin{tabular}{cccc}
\hline Complex & $\mu_{\text {eff }}$ & Frequency, $\mathrm{cm}^{-1}$ & Assignments \\
\hline Cu-BNTM & 1.72 & 12870 & ${ }^{2} \mathrm{Eg} \rightarrow{ }^{2} \mathrm{~T}_{2} \mathrm{~g}$ \\
Co-BNTM & 4.3 & 15015 & ${ }^{4} \mathrm{~T}_{1} \mathrm{~g}(\mathrm{~F}) \rightarrow{ }^{4} \mathrm{~T}_{2} \mathrm{~g}(\mathrm{~F})$ \\
& & 20040 & ${ }^{4} \mathrm{~T}_{1} \mathrm{~g}(\mathrm{~F}) \rightarrow{ }^{4} \mathrm{~A}_{2} \mathrm{~g}(\mathrm{~F})$ \\
& 2.8 & 26881 & ${ }^{4} \mathrm{~T}_{1} \mathrm{~g}(\mathrm{P}) \rightarrow{ }^{4} \mathrm{~T}_{1} \mathrm{~g}(\mathrm{~F})$ \\
Ni-BNTM & & 21834 & ${ }^{3} \mathrm{~A}_{2} \mathrm{~g} \rightarrow{ }^{3} \mathrm{~T}_{2} \mathrm{~g}(\mathrm{~F})$ \\
& & 24875 & ${ }^{3} \mathrm{~A}_{2} \mathrm{~g} \rightarrow \mathrm{T}_{1} \mathrm{~g}(\mathrm{~F})$ \\
VO-BNTM & 1.67 & 30864 & ${ }^{3} \mathrm{~A}_{2} \mathrm{~g} \rightarrow{ }^{3} \mathrm{~T}_{1} \mathrm{~g}(\mathrm{P})$ \\
& & 12853 & ${ }^{2} \mathrm{E} \rightarrow{ }^{2} \mathrm{~B}_{2}$, \\
Mn-BNTM & 4.82 & 23474 & ${ }^{2} \mathrm{~B}_{1} \rightarrow{ }^{2} \mathrm{~B}_{2}$ \\
& & 21321 & ${ }^{2} \mathrm{~A}_{1} \rightarrow{ }^{2} \mathrm{~B}_{2}$ \\
& & 24154 & ${ }^{6} \mathrm{~A}_{1} \mathrm{~g} \rightarrow{ }^{4} \mathrm{~T}_{1} \mathrm{~g}\left({ }^{4} \mathrm{G}\right)$ \\
& & 27173 & ${ }^{6} \mathrm{~A} \mathrm{~A} \rightarrow{ }^{4} \mathrm{E}_{2} \mathrm{~g} g\left({ }^{4} \mathrm{D}\right)$ \\
& & 29411 & $\left.{ }^{6} \mathrm{~T}_{1} \mathrm{~g} g \rightarrow{ }^{4} \mathrm{P}\right)$ \\
& & - & - \\
\hline Zn-BNTM & Diamagnetic & & - \\
\hline
\end{tabular}


The VO(IV) complex exhibited three transitions at 12853,17953, $23474 \mathrm{~cm}^{-1}$, which are assignable to ${ }^{2} \mathrm{E} \rightarrow{ }^{2} \mathrm{~B}_{2},{ }^{2} \mathrm{~B}_{1} \rightarrow{ }^{2} \mathrm{~B}_{2} \&{ }^{2} \mathrm{~A}_{1} \rightarrow{ }^{2} \mathrm{~B}_{2}$ respectively, that are characteristic of octahedral geometry ${ }^{17}$. The diamagnetic $\mathrm{Zn}$ (II) complex did not show any d-d bands and their spectra are dominated by charge transfer bands $23500-25000 \mathrm{~cm}^{-1}$ was assigned due to transition ${ }^{2} \mathrm{Eg} \rightarrow \mathrm{T}_{2} \mathrm{~g}$ possibly in an octahedral environment.

\section{${ }^{1} H N M R \&{ }^{13} C N M R$}

The ${ }^{1} \mathrm{H}$ NMR $\&{ }^{13} \mathrm{C}$ NMR spectral data of the ligand is summarized in the Table 4. A sharp singlet at 8.58 assignable to azomethine proton $(-\mathrm{CH}=\mathrm{N}-)$ confirms the formation of the ligand as proposed. The ${ }^{13} \mathrm{C}$ NMR spectrum of the ligand showed the presence of eight magnetically non equivalent carbons and thus provides an additional evidence for the proposed structure of the ligand.

Table 4. ${ }^{1} \mathrm{H} \&{ }^{13} \mathrm{C}$ NMR data of the Schiff base

\begin{tabular}{lccc}
\hline & ${ }^{1} \mathrm{H}$ & \multicolumn{2}{c}{${ }^{13} \mathrm{C}$} \\
\hline$\delta \mathrm{ppm}$ & Assignment & $\delta \mathrm{ppm}$ & Assignment \\
\hline $8.5(1 \mathrm{H}, \mathrm{s})$ & $-\mathrm{CH}=\mathrm{N}-$ & 157 & $-\mathrm{CH}=\mathrm{N}-$ \\
$5.1(2 \mathrm{H}, \mathrm{s})$ & $-\mathrm{CH} 2-$ & 57 & $-\mathrm{CH} 2-$ \\
$10(1 \mathrm{H}, \mathrm{s})$ & $-\mathrm{NH}-$ & - & - \\
$7.8-7.2$ & Benzimidazole \& & $122,127129,131,14$ & Benzimidazole \& \\
& thiophene rings protons & 1,152 & thiophene ring carbons \\
\hline
\end{tabular}

ESR spectra of $\mathrm{Cu}(\mathrm{II})$ complex

The ESR spectral studies of $\mathrm{Cu}(\mathrm{II})$ complex provide information of the metal ion environment. The ESR spectrum of the $\mathrm{Cu}(\mathrm{II})$ complex was recorded in DMSO at liquid nitrogen temperature (LNT). This complex in the frozen state at $77 \mathrm{~K}$ shows four slightly resolved peaks of low intensities in the low field region and one intense peak in the high field region. In distorted octahedral and square planar complexes, the unpaired electron lies in the $\mathrm{d}_{\mathrm{x}-\mathrm{y}}^{2}$ orbital giving ${ }^{2} \mathrm{~B}_{1} \mathrm{~g}$ as the ground state with $\mathrm{gII}>\mathrm{g} \perp(2.29>2.07)$ and $\mathrm{g}_{\mathrm{avg}}$ is calculated as 2.143, which suggests that the complex is having distorted octahedral geometry. Also it is supported by the fact that the unpaired electron lies predominantly in the $\mathrm{d}_{\mathrm{x}-\mathrm{y}}^{2}$ orbital. ESR spectrum of Cu-BNTM is given in the Figure 2.

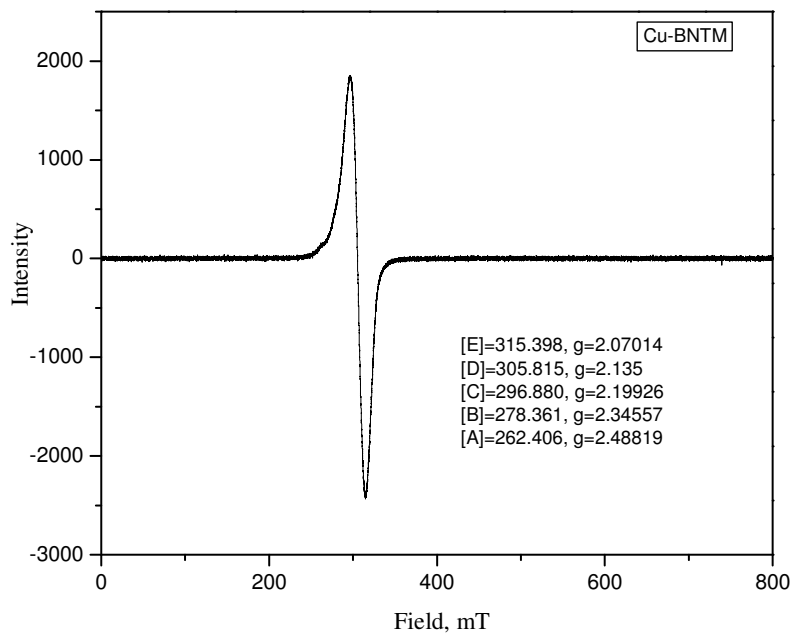

Figure 2. ESR spectrum of Cu-BNTM 


\section{Thermal analysis (TGA \& DTA)}

Thermogravimetric analysis of thermal stability of the metal complex is used: (i) to get information about the metal complexes, (ii) to decide whether the water molecule (if present) are inside or outside the inner coordination sphere of the central metal ion. In the present investigation, heating rates were suitably controlled at $10{ }^{0} \mathrm{C} \mathrm{min}{ }^{-1}$ under nitrogen atmosphere and the weight loss was measured from the ambient temperature up to $\approx 1000{ }^{\circ} \mathrm{C}$. The TGA curves of Cu-BNTM show that the initial mass loss occurring with $90-100{ }^{\circ} \mathrm{C}$ range is interpreted as loss of lattice water molecules and the second weight loss at 200-300 ${ }^{\circ} \mathrm{C}$ range is due to coordinated water molecules. In this complex, rapid weight loss was observed around $500{ }^{\circ} \mathrm{C}$, indicative of decomposition of coordinated ligand. Finally, the horizontal nature of thermogram above $700{ }^{\circ} \mathrm{C}$ observed, suggests the formation of final decomposition products corresponding to the metal oxide. Presence of water molecules is further confirmed by the endothermic bands observed in the DTA curve in the temperature region where the TGA curves should loss in weight. In addition to the endothermic bands, the DTA curves of the complex also show exothermic bands. These bands appeared at higher temperature which represents phase transfer, oxidation and/or decomposition of the compound. Representative thermogram of $\mathrm{Cu}-\mathrm{BNTM}$ is given in the Figure 3.

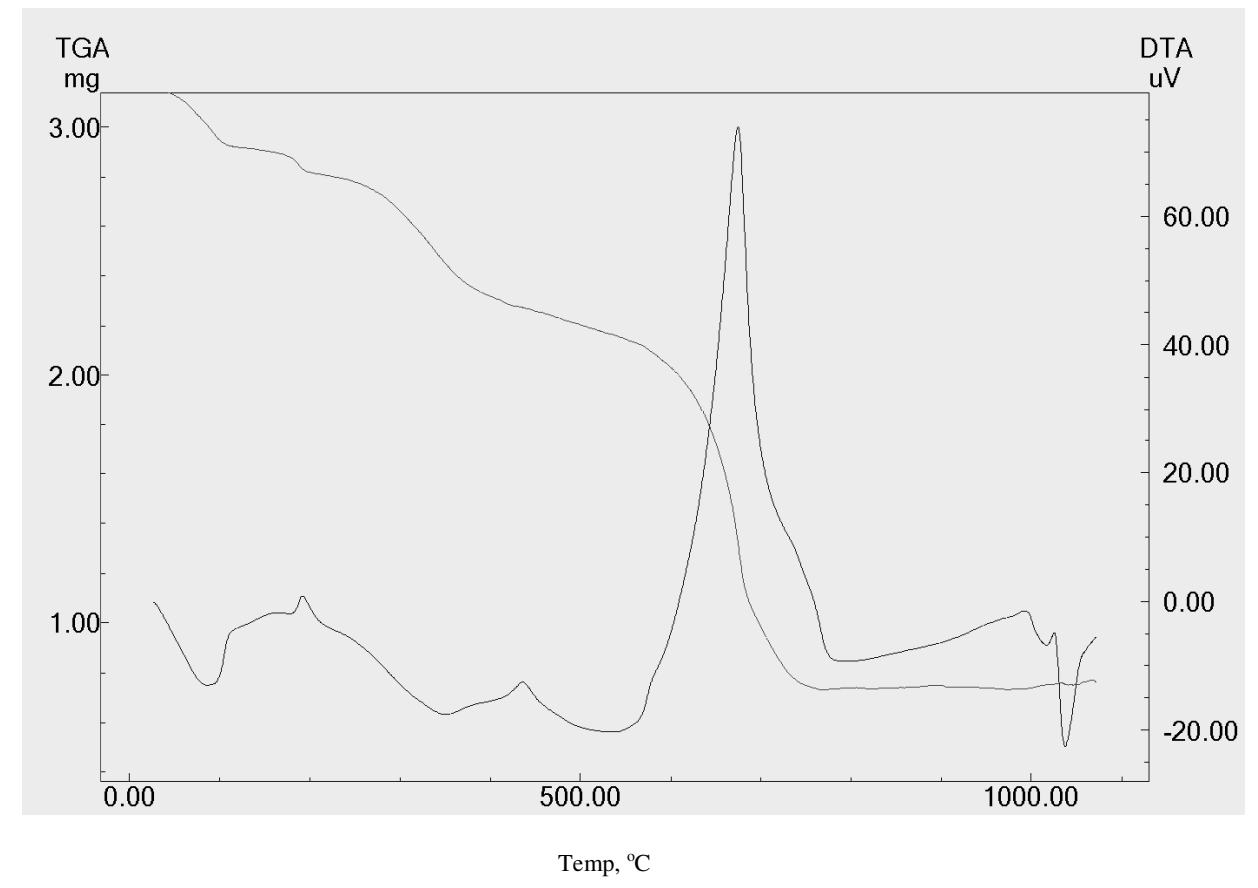

Figure 3. TG-DTA thermogram

\section{Molecular modeling studies}

The possible geometries of metal complexes were evaluated using the molecular calculation with Arguslab 4.0.1 version software. The metal complexes were built and geometry optimization was done using molecular mechanics uniform force field (UFF) method. The molecular modeling pictures and the energies of metal complexes are shown in the Figure 4. 


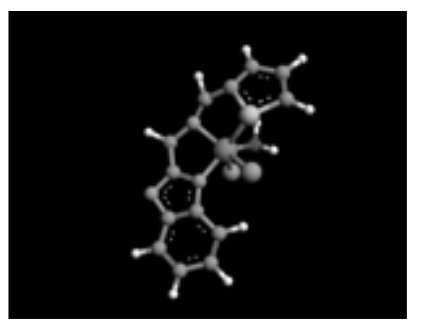

$\left[\mathrm{Zn}(\mathrm{BNTM})\left(\mathrm{H}_{2} \mathrm{O}\right) \mathrm{Cl}_{2}\right]$ $(392 \mathrm{~K} . \mathrm{cal} / \mathrm{mol})$

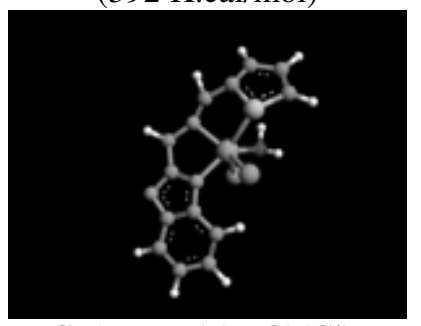

$\left[\mathrm{Cu}(\mathrm{BNTM})\left(\mathrm{H}_{2} \mathrm{O}\right)(\mathrm{Cl})_{2}\right]$ (367 K.cal $/ \mathrm{mol})$

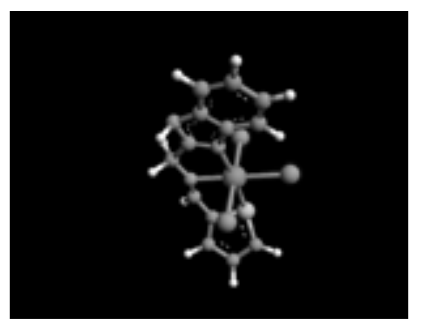

$\left[\mathrm{Mn}(\mathrm{BNTM})(\mathrm{Cl})_{3}\right]$ $(303 \mathrm{~K} . \mathrm{cal} / \mathrm{mol})$

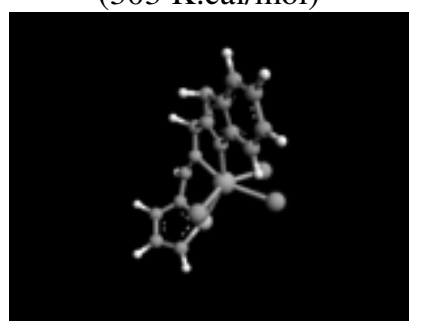

$\left[\mathrm{Co}(\mathrm{BNTM})(\mathrm{Cl})_{3}\right]$ (335 K.cal $/ \mathrm{mol})$

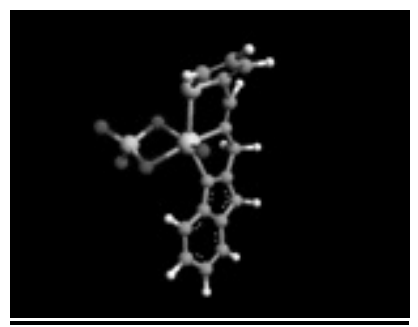

$\left[\mathrm{VO}(\mathrm{BNTM}) \mathrm{SO}_{4}\right]$ $(607 \mathrm{~K} . \mathrm{cal} / \mathrm{mol})$

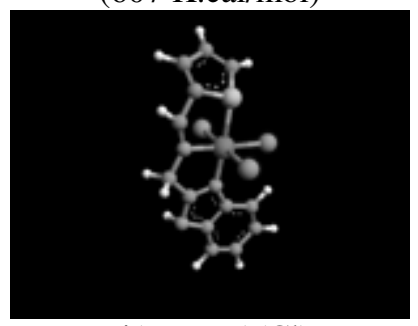

$\left[\mathrm{Ni}(\mathrm{BNTM})(\mathrm{Cl})_{3}\right]$ $(348 \mathrm{~K} . \mathrm{cal} / \mathrm{mol})$

Figure 4. Molecular modelling structures for metal complexes

\section{Antibacterial studies}

The new Schiff base and the complexes were tested for in vitro antibacterial activity against Bacillus subtilis, Staphylococcus aureus, Escherichia coli, Pseudomonas aeruginosa using diffusion method ${ }^{18}$. The diffusion method requires filter paper disks, the medium used is mullerhinton agar with $2 \%$ of glucose and the diameter of inhibition zone is visually read at $24 \mathrm{~h}$ after incubation at $37{ }^{\circ} \mathrm{C}$. The compounds were added on to the filter paper containing this medium. The antimicrobial activity was estimated on the basis of the size of inhibition zone formed around the paper disks on the seeded agar plates. Streptomycin was used as standard. DMSO was used as solvent control for antimicrobial activities. The Schiff base and the complexes exhibited varying degrees of inhibitory effect on the growth of the tested bacterial species. The values reveal that the Schiff base became more effective when coordinated to the metal ions. Such increased activity of the metal chelates is due to lipophilic nature of the metal ions in complexes $^{19}$. Furthermore, the mode of action of the compounds may involve the formation of a hydrogen bond through the azomethine nitrogen with the active centers of the cell constituents resulting in interferences with the normal cell process ${ }^{20}$. The results are presented in the Table 5.

Table 5. Antibacterial activity data for Schiff base and its metal complexes

\begin{tabular}{cccccccccc}
\hline \multirow{2}{*}{ Compound } & \multicolumn{2}{c}{ B.Subtilis } & \multicolumn{2}{c}{ S.Aureus } & \multicolumn{3}{c}{ E.coli } & \multicolumn{3}{c}{ P. Aeruginosa } \\
\cline { 2 - 9 } & $30 \mu \mathrm{L}$ & $60 \mu \mathrm{L}$ & $30 \mu \mathrm{L}$ & $60 \mu \mathrm{L}$ & $30 \mu \mathrm{L}$ & $60 \mu \mathrm{L}$ & $30 \mu \mathrm{L}$ & $60 \mu \mathrm{L}$ \\
\hline Schiff base & + & ++ & + & ++ & + & ++ & + & ++ \\
Cu complex & ++ & ++++ & ++ & +++ & + & +++ & ++ & ++++ \\
Co complex & +++ & ++++ & +++ & ++++ & +++ & ++++ & +++ & ++++ \\
Ni complex & ++ & ++++ & + & +++ & + & +++ & + & +++ \\
Zn complex & -- & -- & ++ & ++ & -- & -- & -- & -- \\
OV complex & ++ & +++ & + & +++ & ++ & +++ & ++ & +++ \\
Mn complex & +++ & ++++ & +++ & ++++ & +++ & +++ & + & +++ \\
\hline
\end{tabular}

Inhibition zone diameter: $+=8-10 \mathrm{~mm} ;++=10-14 \mathrm{~mm} ;+++=14-18 \mathrm{~mm} ;++++=18-26 \mathrm{~mm} ;--=$ no activity 


\section{Conclusion}

$\mathrm{Cu}(\mathrm{II}), \mathrm{Co}(\mathrm{II}), \mathrm{Ni}(\mathrm{II}), \mathrm{Mn}(\mathrm{II}), \mathrm{OV}(\mathrm{IV})$ and $\mathrm{Zn}(\mathrm{II})$ complexes of the Schiff base derived from 2-(aminomethyl)benzimidazole and thiophene-2-carbaxaldehyde were prepared and characterized. The study reveals that (i) $\mathrm{Cu}$ (II), $\mathrm{Zn}$ (II) and $\mathrm{VO}$ (IV) complexes are nonelectrolytes and $\mathrm{Co}(\mathrm{II}), \mathrm{Ni}(\mathrm{II})$ and $\mathrm{Mn}(\mathrm{II})$ complexes are 1:2 electrolytes; (ii) The Schiff base behaves as a neutal tridentate ligand and is coordinated through the azomethine nitrogen, spyridyl nitrogen of benzimidazole moiety and thiophene S; (iii) All the metal complexes have octahedral geometry and (iv) The biological activity of all the complexes is higher than that of the free schiff base ligand.

\section{References}

1. Raman N, Thangaraja A and Kulandaisamy C, Trans Met Chem., 2003, 28, 29-36.

2. Amirnasr M, MahmoudKhani A H, Gorji A, Dehghanpour S and Bijanzadeh H R, Polyhedron, 2002,21,2733.

3. Chohan Z H, Rauf A and Supuran C T, Metal Based Drugs, 2002, 8, 287.

4. Mohamed G G, Omar M M and Hindy A M M, Spectrochim Acta Part A, 2005, 62, $1140-1150$.

5. Ismil K Z, Dissouky A E and Shehada A Z, Polyhedron, 1997, 16(17), 2909-2916.

6. Sharghi H and Nasseri M A, Bull Chem Soc (Jpn), 2003, 76, 137-142.

7. Goker H, Alp M and Yildiz S, Molecules, 2005, 10(11), 1377-1386.

8. Paltzold F, Zeuner F, Heyer T H and Niclas H J, Synth Commun., 1992, 22, 281.

9. Seema Varghese and Muraleedharan Nair M K, RJPBCS, 2010, 1(2), 347.

10. Prashanthi Y and Shivaraj, J Sci Res., 2010, 2(1), 114-126.

11. Aly M A Hassan, J Islamic Academy Sci., 1991, 4, 271-274.

12. Poonam S Deshmukh, Amit R Yaul, Jayashree N Bhojane and Aanad S Aswar, World J Chem., 2010, 5(1), 57.

13. Mozaffar Asadi, Mohammad Hadi Ghatee, Susan Torabi, Khosro Mohammadi and Fatemeh Moosavi, J Chem Sci., 2010, 122(4), 539-548.

14. Hamdi Temel, Umit Cakır and Ibrahim Ugras I, Synth React Inorg Met-Org Chem., 2004, 34, 819.

15. Nakamoto K, Infrared and Raman Spectra of Inorganic and Coordination Compounds, Part A \& Part B, Newyork, NY, USA; John Wiley \& Sons, 1998.

16. Silverstein R M, Bassler G C, Morril T C, Spectroscopic identification of organic compounds, $5^{\text {th }}$ Edn., Newyork, NY, USA, Johnwiley \& Sons, 1991

17. Lever A B P, Inorganic Electronic Spectra, Elsevier, Newyork, 1984.

18. ZottaV, (Ed), Chimie Farmaceutica, Medicala;Bucuresti,1985, 67.

19. Singh R, srivasthava J P and Mishra L K, Indian J Chem., 1993, 32A, 446.

20. Dharmaraj N, Vishwanathamurthi P and Natarajan K, Trans Met Chem., 2001, 26, 105. 


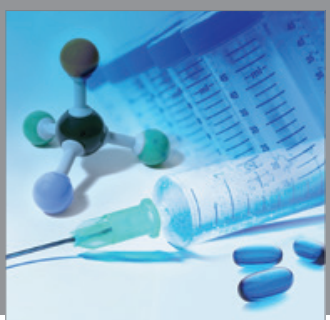

International Journal of

Medicinal Chemistry

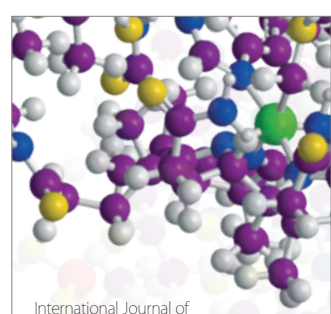

Carbohydrate Chemistry

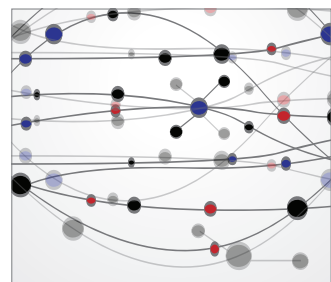

The Scientific World Journal
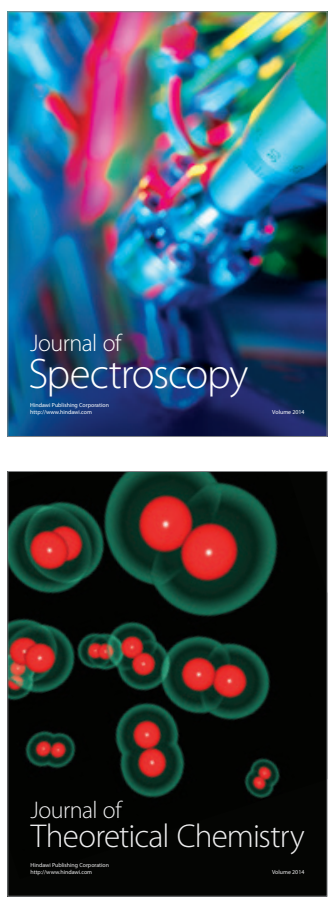
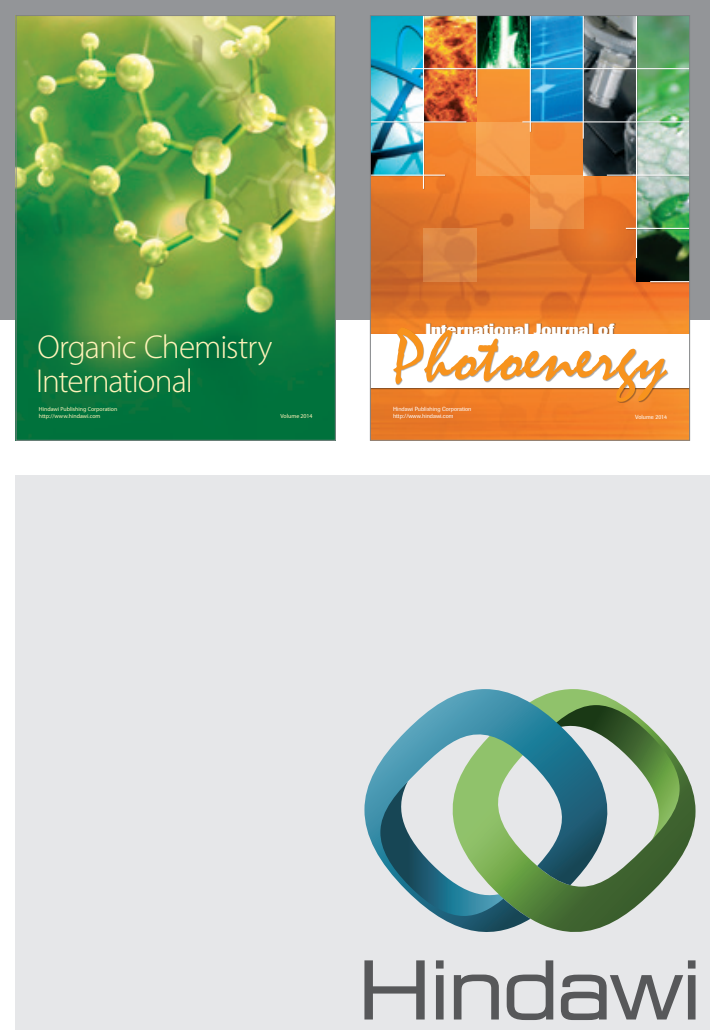

Submit your manuscripts at

http://www.hindawi.com
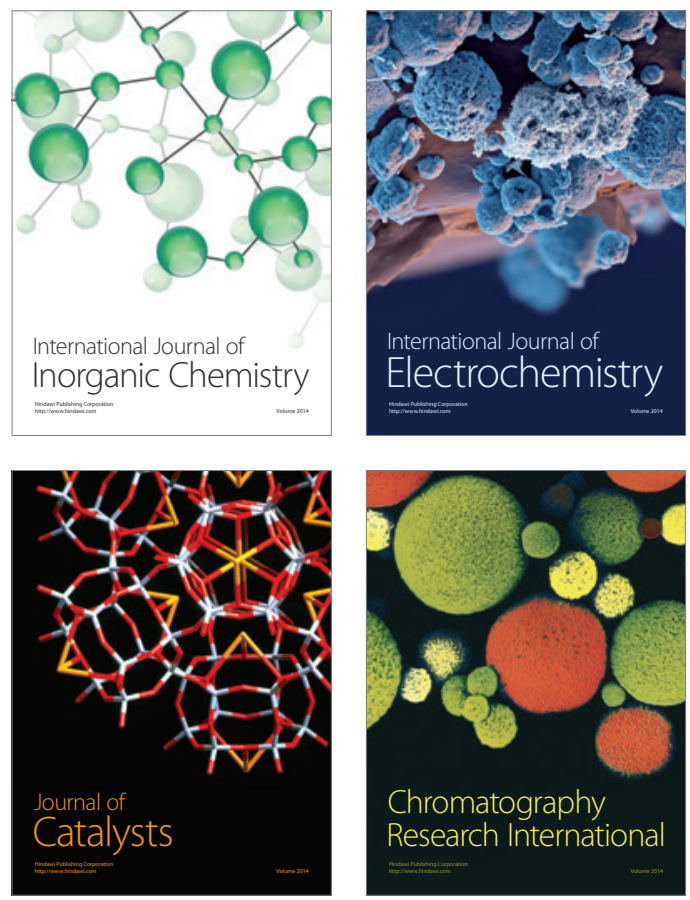
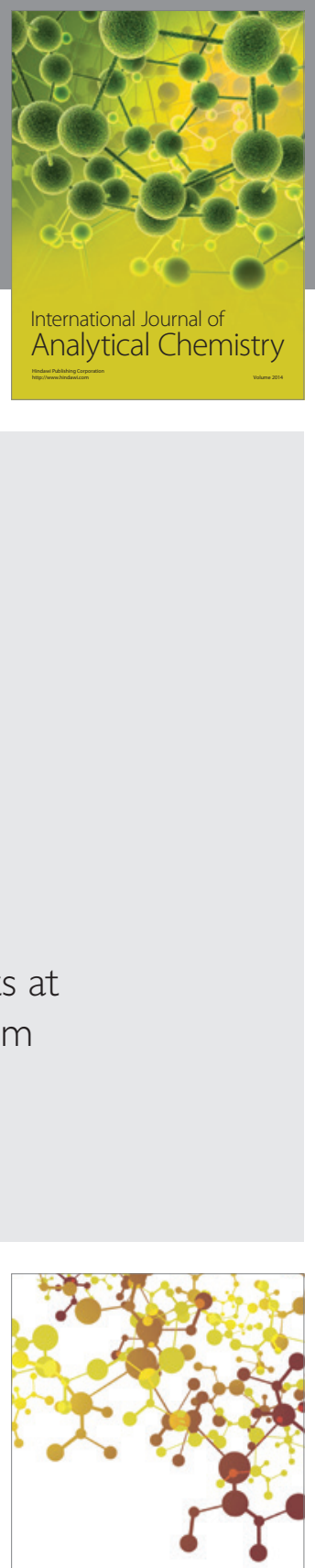

Journal of

Applied Chemistry
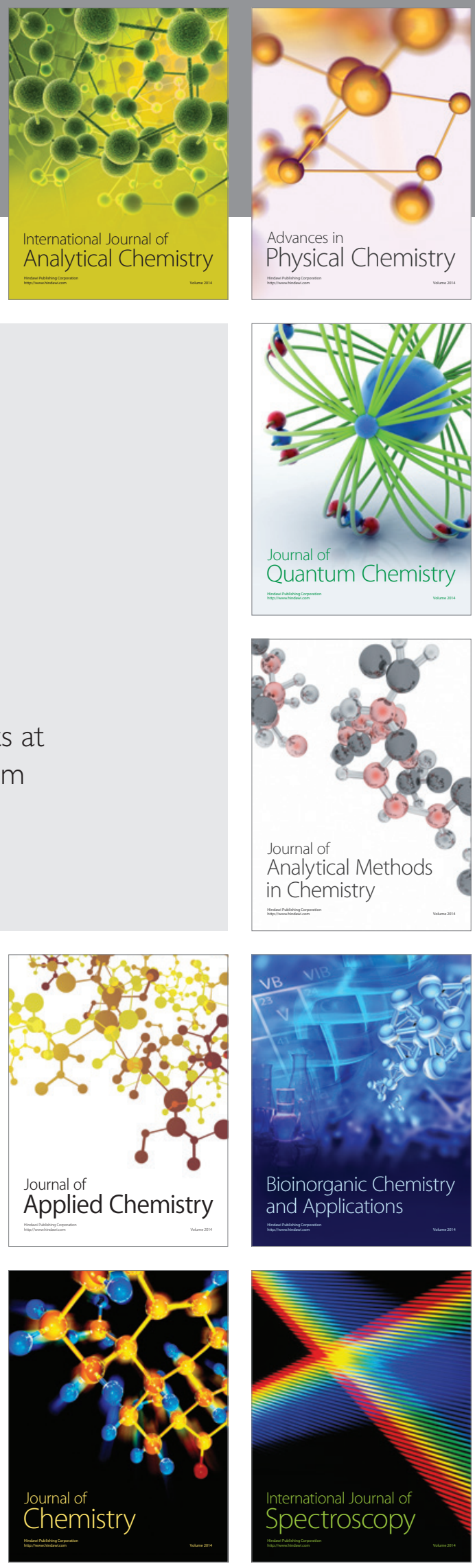